\title{
EFFECTIVENESS OF HOLISTIC SELF CARE TO OVERCOME WORK- RELATED SKELETAL MUSCLE DISORDER IN PALM WORKERS USING HARVASTING TOOL DODOS: A SYSTEMATIC REVIEW
}

\author{
Siti Umairah, Vanessa Adela Putri, Rosyida, Raihanatu Binqalbi Ruzain
}

Psychology Study Program, Faculty of Psychology, University of Islamic Riau

\begin{abstract}
Background: Oil palm Dodos workers manually harvest the palm fresh fruit which can cause work related musculoskeletal disorders (WMSDS). Holistic self-care by combining stretching exercises and breathing techniques is believed to be able to overcome work related skeletal muscle disorders. The study aimed to conduct a systematic review of research articles identifying the effectiveness of holistic self-care in overcoming workrelated skeletal muscle disorders in Riau palm Dodos workers, and identifying the frequency of implementing holistic self-care.

Subject and Method: A systematic review was conducted through electronic database, including Google scholar, Science Open, and ScienceDirect. The keywords used were "musculoskeletal disorders" AND "stretching exercise" AND "breathing technique". The articles were collected between 2009 to 2020.

Results: The article analysis used in this study were 4 articles. The effectiveness of holistic self-care (stretching exercise and breathing technique) showed 30 minutes of exercise per day for 5 days per week for a period of 6 weeks can overcome the skeletal muscle disorders caused by work related neck, shoulder, upper, and low back pain in workers.

Conclusion: Holistic self-care (stretching exercise and breathing technique) overcomes work related musculoskeletal disorders in workers.
\end{abstract}

Keywords: work related musculoskeletal disorders, holistic self-care.

Correspondence:

Siti Umairah. Psychology Study Program, Faculty of Psychology, University of Islamic Riau, Pekanbaru, Riau, Indonesia. Email: pujaumayrah@gmail.com.

Mobile: +6282250453378 .

The $7^{\text {th }}$ International Conference on Public Health

Solo, Indonesia, November 18-19, $2020 \mid 150$

https://doi.org/10.26911/the7thicph.02.39 